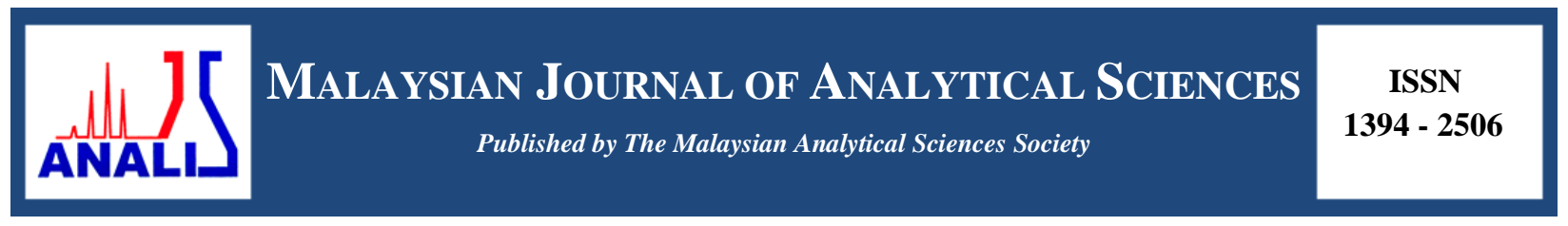

\title{
MONOETHANOLAMINE WASTEWATER TREATMENT VIA ADSORPTION USING WOOD SAWDUST BASED ACTIVATED CARBON
}

\section{(Rawatan Air Sisa Monoetanolamina Melalui Kaedah Penjerapan Menggunakan Karbon Habuk Kayu Yang Diaktifkan)}

\author{
Azry Borhan $^{1}$, Tong Yeong Yit $^{1}$, Suzana Yusup ${ }^{1}$, Normawati Mohd Yunus ${ }^{2}$ \\ ${ }^{1}$ Department of Chemical Engineering \\ ${ }^{2}$ Department of Fundamental and Applied Sciences \\ Universiti Teknologi Petronas, 32610 Bandar Seri Iskandar, Perak, Malaysia \\ *Corresponding author: azrybo@utp.edu.my
}

Received: 16 April 2017; Accepted: 7 March 2018

\begin{abstract}
In this work, sawdust, which is low cost and produced abundantly from wood industry, was tested as a precursor for the production of porous carbons in a chemical scheme using $\mathrm{H}_{3} \mathrm{PO}_{4}$. From synthesis parameters studied, F21 activated carbon with the largest surface area, total pore volume and diameter was obtained when sawdust is impregnated with ratio of 1:1 and treated with activation temperature of $500{ }^{\circ} \mathrm{C}$ for a period of 60 minutes. Through nitrogen adsorption-desorption isotherm analysis, existence of mesopores was proven when a combination of Type-I and Type-II isotherms were exhibited by the activated carbon produced. The results from adsorption test showed that under the effect of initial concentration, the optimum sample is capable of removing $96.8 \%$ of MEA at low concentration of $100 \mathrm{ppm}$, while under the effect of stirring rate, $99.7 \%$ of MEA is removed at highest stirring rate at $400 \mathrm{rpm}$. Finally under the effect of contact time, $99.7 \%$ of MEA removal is achieved at time of 45 minutes. The obtained results show that agriculture waste product from sawdust can be effectively used as an adsorption material in MEA wastewater treatment.
\end{abstract}

Keywords: wood sawdust, monoethanolamine, chemical activation, activated carbon, adsorption

\section{Abstrak}

Di dalam kajian ini, habuk papan, yang berkos rendah dan dihasilkan dengan banyak dari industri kayu, telah diuji sebagai pemula untuk pengeluaran karbon berliang dalam skim kimia menggunakan $\mathrm{H}_{3} \mathrm{PO}_{4}$. Dari parameter sintesis yang dikaji, F21 karbon yang diaktifkan menghasilkan luas permukaan, jumlah isi padu dan diameter berliang terbesar diperolehi apabila habuk papan diimpregnasikan dengan nisbah 1:1 dan dirawat dengan suhu pengaktifan $500{ }^{\circ} \mathrm{C}$ untuk tempoh 60 minit. Melalui analisis isoterma penjerapan nitrogen, kewujudan liang meso terbukti apabila gabungan isotem Jenis-I dan Jenis-II dipamerkan oleh karbon yang diaktifkan. Hasil daripada ujian penjerapan menunjukkan bahawa di bawah kesan kepekatan awal, sampel optimum mampu mengeluarkan 96.8\% daripada monoetanolamina (MEA) pada kepekatan rendah 100 ppm, manakala di bawah kesan kadar kacau, 99.7\% daripada MEA dikeluarkan pada kadar pengadukan tertinggi pada 400 rpm. Akhirnya di bawah kesan waktu hubungan, 99.7\% penyingkiran MEA dicapai pada masa 45 minit. Hasil yang diperoleh menunjukkan bahawa produk sisa pertanian dari habuk papan boleh digunakan dengan berkesan sebagai bahan penjerap dalam rawatan air buangan MEA.

Kata kunci: habuk papan kayu, monoetanolamin, pengaktifan kimia, karbon diaktifkan, penjerapan 


\section{Azry et al: MONOETHANOLAMINE WASTEWATER TREATMENT VIA ADSORPTION USING WOOD SAWDUST BASED ACTIVATED CARBON}

\section{Introduction}

In petrochemical industry, especially in natural gas processing plant, raw natural gas contains significant amount of carbon dioxide $\left(\mathrm{CO}_{2}\right)$. Prior to further processing activities, the gas stream needs to undergo treatment to remove $\mathrm{CO}_{2}$ to meet specifications for successful liquefaction LNG process. The most important commercially applied technology for $\mathrm{CO}_{2}$ removal is the absorption process by using amine-based solvent. One of the important amines is monoethanolamine (MEA) which is used in most acid gas recovery system as it provides sufficient alkalinity to absorb $\mathrm{CO}_{2}$ [1]. However, during absorption-desorption, maintenance and transportation activities, amine may degrade over time and this corrosive by-products may be carried over and need to be removed as wastewater. Amines are known as toxic material and can have significant affect to human health and the aquatic ecosystem [2]. MEA is an organic matter and can upset the water stream by increasing the Chemical Oxygen Demand (COD). A high COD reading indicates oxygen deficiency in water. Decomposition of organic matter will consume the amount of water-dissolved oxygen, which in turns leads to lack of oxygen and ultimately destroy the aquatic ecosystem. It is common, in the range of $60-80$ tons of MEA wastewater is generated per month [3]. In view of the fact that MEA wastewater is produced abundantly from petrochemical plants as well as other processing plants such as coal fired power station and ammonia synthesis plant, it is essential to identify the alternative route methods for treating MEA wastewater which is inexpensive, simple, economically viable and environmental friendly. One of the effective ways is by adsorption method using activated carbon (AC).

AC in its broadest definition includes a wide range of carbonaceous materials prepared to exhibit a high degree of porosity and an extended interparticulate surface area. The first-class features of high porosity and large surface area impart AC with excellent adsorptive characteristics, which make carbon very useful in many industrial processes such as filtration, separation, decolourization and purification $[3,4]$. The versatility of this product is notably observed in the fact that it can be produced from a variety of raw materials. Among them, wood is by far the most common source of precursor, followed closely by coal, coconut shell and other biomass [5, 6]. In Malaysia, the growth of wood-based industry has been phenomenal over the past decades. Malaysia with its well-known tropical rainforest climate is considered as the most ideal climatic condition for cultivating timber, and this potential has been fully utilized and exploited. According to Malaysian Investment Development Authority (MIDA) [7], a total of 1025 sawmills operating in Malaysia has made it into becoming one of the major timber supplier in Southeast Asia region, with exports of saw logs and sawn timber in 2015 amounted to RM6.1 billion. However, the intense wood processing activities has led to generation of substantial amount of byproducts in the form of sawdust, offcut and wood barks [8]. Managing considerable quantities of residues in the form of sawdust and wood chips has become a challenge for the industry and the problem is indeed of great concern. To effectively manage the issue, waste minimization programs were carried out with the intent to reclaim this useful material. In line with the zero waste concept of viewing waste as a potential resource with value to be realized, sawdust has been shown to have potential as precursor material in the preparation of $\mathrm{AC}$ and is able to be transformed into value-added products rather than as a waste management problem to be dealt with.

High quality AC are manufactured through activation and carbonization of carbonaceous materials [9]. These carbon-based materials need to be activated and carbonized through a series of optimum processes to draw out and make full use of its enormous potential. The resultant products often have high adsorptive capacities, which are associated with their internal porosity and are related to properties such as surface area, pore volume and pore size distribution [10]. Basically, there are two different processes for preparing AC: physical and chemical activation. Physical activation involves the pyrolysis step followed by a stage of controlled oxidation to activate the carbon in the presence of steam or $\mathrm{CO}_{2}$ [11]. Chemical activation, on the other hand, is a single step method consisting carbonization at a relatively low temperature in the presence of chemical activating agent. [5, 12]. Present study chose to employ chemical activation method due to numerous advantages over physical activation. In the process of chemical activation, the yield is relatively high, and activation temperature is low making the process more economical compared to physical activation [9, 13]. It is more common to use chemical activation when the material is of wood origin [14]. Zhang et al. [15] claim that AC in chemical activation usually has a relatively higher specific surface area and more mesopores than that in physical activation. The main chemical activating agents used include zinc chloride $\left(\mathrm{ZnCl}_{2}\right)$, phosphoric acid $\left(\mathrm{H}_{3} \mathrm{PO}_{4}\right)$ and potassium hydroxide $(\mathrm{KOH})$ solution. These chemical reagents generally act as the dehydrating agents and may promote the formation of cross-links. $\mathrm{H}_{3} \mathrm{PO}_{4}$ and $\mathrm{ZnCl}_{2}$ are more suitable for activating a lignocellulosic material; whereas $\mathrm{KOH}$ is normally used for activation of coal 
precursor or chars [12]. When compared with $\mathrm{ZnCl}_{2}$, the use of $\mathrm{H}_{3} \mathrm{PO}_{4}$ is more favoured due to problems of environmental contamination with zinc compounds $[7,10]$.

In this study, chemical activation method by $\mathrm{H}_{3} \mathrm{PO}_{4}$ was selected due to its numerous advantages over physical activation method and favourable conditions compared to other chemical activating agents. The research study was set in the direction towards evaluating the potential of sawdust and to compare its effectiveness in adsorbing MEA from aqueous solution. Since chemical activation was adopted in this study, impregnation ratio, temperature and activation time would be the main factors affecting the extent of reaction. Therefore, these parameters were also investigated to assess the effects of operation conditions on pore development of activated carbon prepared from sawdust.

\section{Sample preparation}

\section{Materials and Methods}

Fresh sawdust produced from the process of converting the raw logs into sawn timber was collected from a local sawmill for experimental purpose. The type of sawdust acquired was originated from Nyatoh wood or scientifically known as Sapotaceae spp., classified as species of light hardwood. The sawdust collected was sieved according to size of $250 \mu \mathrm{m}$. The sieved sawdust was then washed with distilled water several times to remove impurities and ashes that were collected together. After washing, the sawdust was dried in an oven overnight at $80{ }^{\circ} \mathrm{C}$ constant heating rate to preserve the samples [5]. The dried and cleaned sawdust was placed in a desiccator for further process. All chemicals were purchased from R \& M Chemicals and were industrial reagent grade.

\section{Carbonization and activation}

The sawdust prepared was impregnated by mixing it with desired ratio $\left(1: 1,1: 2\right.$, and 1:3) of $\mathrm{H}_{3} \mathrm{PO}_{4}$ based on the dry weight of the sample. The impregnation ratio is given by:

$$
\text { Impregnation ratio, } \mathrm{IR}=\frac{\mathrm{W}_{\mathrm{H} 3 \mathrm{PO} 4}}{\mathrm{~W}_{\text {sawdust }}}
$$

where $\mathrm{W}_{\mathrm{H} 3 \mathrm{PO} 4}$ is the dry weight of phosphoric acid and $\mathrm{W}_{\text {sawdust }}$ is the dry weight of sawdust [12]. The impregnation process was allowed to sit for overnight to ensure complete reaction takes place between the chemical reagent and raw material. The impregnated material was then carbonized in a fixed bed activation unit with heating temperature ranging from $400,500,600$ to $700{ }^{\circ} \mathrm{C}$ and activation time of 30, 60, 90 and 120 minutes. The one-factor-at-a-time (OFAT) method was adopted in this study so that reduction of sample is achievable; it is a method of designing experiments involving the testing of factors one at a time instead of all simultaneously. Throughout the process, nitrogen gas, which acts as the carrier gas and promotes the pore formation in sawdust, was allowed to flow in the rotary kiln [5]. After the heat treatment, the material was left to cool to room temperature and subsequently washed with distilled water to remove the residual $\mathrm{H}_{3} \mathrm{PO}_{4}$ solution. The carbon sample produced was dried in an oven for overnight at $80^{\circ} \mathrm{C}$ and kept in a desiccator to prevent moisture.

\section{Adsorption analysis}

The batch experiment was carried out using UV-Vis Spectrophotometer set at wavelength of $195 \mathrm{~nm}$ to detect the concentration of MEA in synthetic MEA wastewater. Calibration was performed using standard solution of 100 ppm, $300 \mathrm{ppm}$ and $500 \mathrm{ppm}$ prepared by diluting MEA (analyte) with distilled water (solvent). The concentration range selected is based on reported MEA discharged into wastewater treatment plant [1]. Effect of initial concentrations $(200,300$ and $400 \mathrm{ppm})$, stirring rate $(100,300$ and $400 \mathrm{rpm})$ and contact time $(15,30$ and 45 minutes) were studied to determine the optimum conditions of the sawdust AC sample prepared. All experiments were conducted at a room temperature of $32{ }^{\circ} \mathrm{C}$ and repeated twice for accuracy. Samples were extracted from the mixture and readings were taken at interval of 10 minutes. The graphs of \% MEA removed versus the above three effects were plotted to study the effectiveness of AC in adsorbing MEA. 


\section{FESEM Analysis}

To determine the best operating parameter for producing AC from sawdust, analytical technique used in material science for investigating the molecular surface structure was employed. A Zeiss EVO-50 Field Emission Scanning Electron Microscope (FESEM), model Supra 55 VP is an equipment designed for high resolution imaging at magnification of $10-100,000$ times, and was used to compare the structural images of sawdust before and after activation by producing real space magnified images of its surface morphology.

\section{Micrometrics ASAP 2020}

Accurate and precise surface area and porosimetry measurements are essential to the determination of the effectiveness and quality of activated carbon samples. The pore size distribution, specific surface area $\left(\mathrm{S}_{\mathrm{BET}}\right)$, porosity volume $\left(\mathrm{V}_{\mathrm{T}}\right)$ and average pore diameter $(\mathrm{D})$ of the $\mathrm{AC}$ samples are determined by nitrogen $\left(\mathrm{N}_{2}\right)$ adsorptiondesorption isotherm isotherm whereby $\mathrm{N}_{2}$ gas playing the role as adsorbate, was set to flow at $350{ }^{\circ} \mathrm{C}$ for 2 hours. The $\mathrm{S}_{\mathrm{BET}}$ of samples are estimated using the Brunauer-Emmett-Teller (BET) method using $\mathrm{N}_{2}$ gas adsorption isotherm data while the Barett-Joyner-Halenda $(\mathrm{BJH})$ adsorption model is used for pore size distribution [11].

\section{Characterization study and EDX spectroscopy}

\section{Results and Discussion}

Table 1 below shows the preparation condition and results of AC samples produced from sawdust. Results showed that sample F21 which was prepared at IR of $1: 1, \mathrm{~T}_{\text {act }}$ of $500{ }^{\circ} \mathrm{C}$ and $\mathrm{t}_{\text {act }}$ of 60 minutes yields the highest value of $\mathrm{S}_{\text {BET }} 1213.786 \mathrm{~m}^{2} / \mathrm{g}$ with $\mathrm{D}$ equals $2.18 \mathrm{~nm}$ and $\mathrm{V}_{\mathrm{T}}$ as high as $0.662 \mathrm{~cm}^{3} / \mathrm{g}$. Whereas sample D15 exhibit lowest characterization of $S_{\mathrm{BET}}\left(58.581 \mathrm{~m}^{2} / \mathrm{g}\right), \mathrm{V}_{\mathrm{T}}\left(0.036 \mathrm{~cm}^{3} / \mathrm{g}\right)$ and $\mathrm{D}(2.573 \mathrm{~nm})$ were obtained at IR of $1: 1, \mathrm{~T}_{\text {act }}$ of 700 ${ }^{\circ} \mathrm{C}$ and $\mathrm{t}_{\text {act }}$ of 30 minutes. In sample B9, B10 and B11, as the impregnation ratio increases, the samples show decreasing $\mathrm{S}_{\mathrm{BET}}$ value with similar trend observed in sample A6, A7 and A8. Impregnation ratio (IR) is a critical parameter in formation of pores because it signifies the amount of ions available for intercalation to take place. An optimum IR of 1:1 to 1:3 has been reported to yield highest surface area carbon [17], and the result obtained shows that highest value is achieved at 1:1 IR. High IR favors more pore formation as it intensify the action of acid with more aggressive physico-chemical effect and dehydration which inhibits the contraction or collapse of the precursor particle. The washing after heat treatment will evacuate and free this internal porosity leaving behind an extensive microporous structure [18].

Table 1. Preparation condition and results of activated carbon samples

\begin{tabular}{lcccccc}
\hline Sample & IR & $\begin{array}{c}\text { Activation } \\
\text { Temperature, } \\
\mathbf{T}_{\text {act }}\left({ }^{\circ} \mathbf{C}\right)\end{array}$ & $\begin{array}{c}\text { Activation } \\
\text { Time, } \\
\mathbf{t}_{\text {act }}(\mathbf{m i n})\end{array}$ & $\begin{array}{c}\text { Specific } \\
\text { Surface Area, } \\
\mathbf{S}_{\mathbf{B E T}}\left(\mathbf{m}^{2} / \mathbf{g}\right)\end{array}$ & $\begin{array}{c}\text { Total Pore } \\
\text { Volume, } \\
\mathbf{V}_{\mathbf{T}}\left(\mathbf{c m}^{\mathbf{3}} \mathbf{g}\right)\end{array}$ & $\begin{array}{c}\text { Average Pore } \\
\text { Diameter, } \\
\mathbf{D}(\mathbf{n m})\end{array}$ \\
\hline Raw & - & - & - & 1.304 & 0.002 & 6.328 \\
A6 & $1: 1$ & 400 & 30 & 474.483 & 0.253 & 2.134 \\
A7 & $1: 2$ & 400 & 30 & 199.333 & 0.107 & 2.153 \\
A8 & $1: 3$ & 400 & 30 & 1.161 & - & - \\
B9 & $1: 1$ & 500 & 30 & 1135.624 & 0.565 & 1.992 \\
B10 & $1: 2$ & 500 & 30 & 878.880 & 0.551 & 2.507 \\
B11 & $1: 3$ & 500 & 30 & 399.013 & 0.261 & 2.616 \\
C12 & $1: 1$ & 600 & 30 & 539.708 & 0.290 & 2.153 \\
D15 & $1: 1$ & 700 & 30 & 58.581 & 0.036 & 2.573 \\
F21 & $1: 1$ & 500 & 60 & 1213.786 & 0.662 & 2.180 \\
J33 & $1: 1$ & 500 & 90 & 1176.079 & 0.634 & 2.158 \\
N45 & $1: 1$ & 500 & 120 & 941.242 & 0.495 & 2.105 \\
\hline
\end{tabular}


Nevertheless, the outcome of the analysis confirms that there is a maximum amount of ions that can be uptake beyond which would reduce pore development. The reason is because additional acid does not lead to further action and probably form an insulating layer (or skin) covering the particles, thus reducing the activation process and the contact with surrounding atmosphere. This phenomenon is particularly observed in sample A8 where most likely activation is hindered, resulting in negligible surface area and undetected pore. Similar trend was observed by Borhan et al. [5] using $\mathrm{H}_{3} \mathrm{PO}_{4}$ for banana peel activation when activated above 1:1 IR. As for activation temperature, the optimum temperatures have been reported to be between 400 to $700{ }^{\circ} \mathrm{C}$ by most of the earlier researchers [17]. Hence the experiments were conducted within the selected temperature range, and it turned out that the recommended temperature is reliable due to verification provided by sample $\mathrm{B} 9$ at $500{ }^{\circ} \mathrm{C}$. The increase in temperature from $600{ }^{\circ} \mathrm{C}$ to $700{ }^{\circ} \mathrm{C}$ for Sample $\mathrm{C} 12$ and D15, clearly demonstrated the collapse of porous structure due to excessive heat energy intake, which results from knocking and breaking of some porous wall [12]. While maintaining a constant impregnation ratio at $1: 1$ and activation temperature at $500{ }^{\circ} \mathrm{C}$, the influence of activation time is examined. The results obtained from sample B9, F21, J33 and N45 show that the optimum time for carbonization is 60 minutes. Prolonged heat exposure would only cause rupture in porous wall. Since the porous structure has already been well developed at temperature of $500{ }^{\circ} \mathrm{C}$, the increase in activation time simply causes the break of the cross-links between carbon structures, with a consequent collapse of pores [16]. All the samples that have been analyzed show average pore diameter of around $2 \mathrm{~nm}$, indicating formation of mesopores.

Aside from examining the surface morphology of the samples, FESEM is also equipped with EDX spectroscopy for detecting the elemental composition. Table 2 shows the comparison of elemental composition before and after activation. Two elements were detected on the sample before activation: carbon and oxygen. It was reported in specific that suitable range of carbon content should lie between 50 to 80\% [6]. The result shows that Nyatoh wood species sawdust fulfills the criterion of producing AC. An additional element identified as phosphorus, $\mathrm{P}$ was detected in the sample after activation. Presence of phosphorus element is due to the use of $\mathrm{H}_{3} \mathrm{PO}_{4}$ as chemical activating agent during the impregnation process. Repetitive washing can further reduce the phosphorus element but complete elimination is hardly possible.

Table 2. Comparison of elemental composition before and after activation

\begin{tabular}{lcccc}
\hline \multirow{2}{*}{ Elements } & \multicolumn{2}{c}{ Before Activation } & \multicolumn{2}{c}{ After activation } \\
\cline { 2 - 5 } & Weight \% & Atomic \% & Weight \% & Atomic \% \\
\hline Carbon, C & 54.98 & 61.93 & 76.86 & 82.45 \\
Oxygen, O & 45.02 & 38.07 & 20.36 & 16.39 \\
Phosphorus, P & 0.00 & 0.00 & 2.78 & 1.16 \\
Total & 100.00 & & 100.00 & \\
\hline
\end{tabular}

\section{$\mathrm{N}_{2}$ adsorption - desorption isotherms}

The existence of mesopores is further proven with the identified isotherms. The objective of this study is to categorize the right adsorption isotherm type based on IUPAC classification [19]. Figure 1 shows the $\mathrm{N}_{2}$ adsorptiondesorption isotherm of some selected samples. The isotherm is plotted as quantity of $\mathrm{N}_{2}$ gas adsorbed against the relative pressure. Based on the six principal types of adsorption isotherms, it is stated that all isotherms produced should fit at least one or a combination of two or more of the shapes [12]. Referring to the graph in

From Figure 1, it can be seen that all selected samples exhibit trends with combination of Type-I and Type-II isotherms except Sample D15 which shows Type-I isotherm. Literature presents that Type-I isotherm is normally observed on microporous solid whose pore sizes are not exceedingly large when compare to the molecular diameter of the adsorbate, whereas Type-II isotherm is found in adsorbents with pore diameters larger than micropores. A combination of these two could be viewed as the effect of mixed micropores and mesopores structure. 


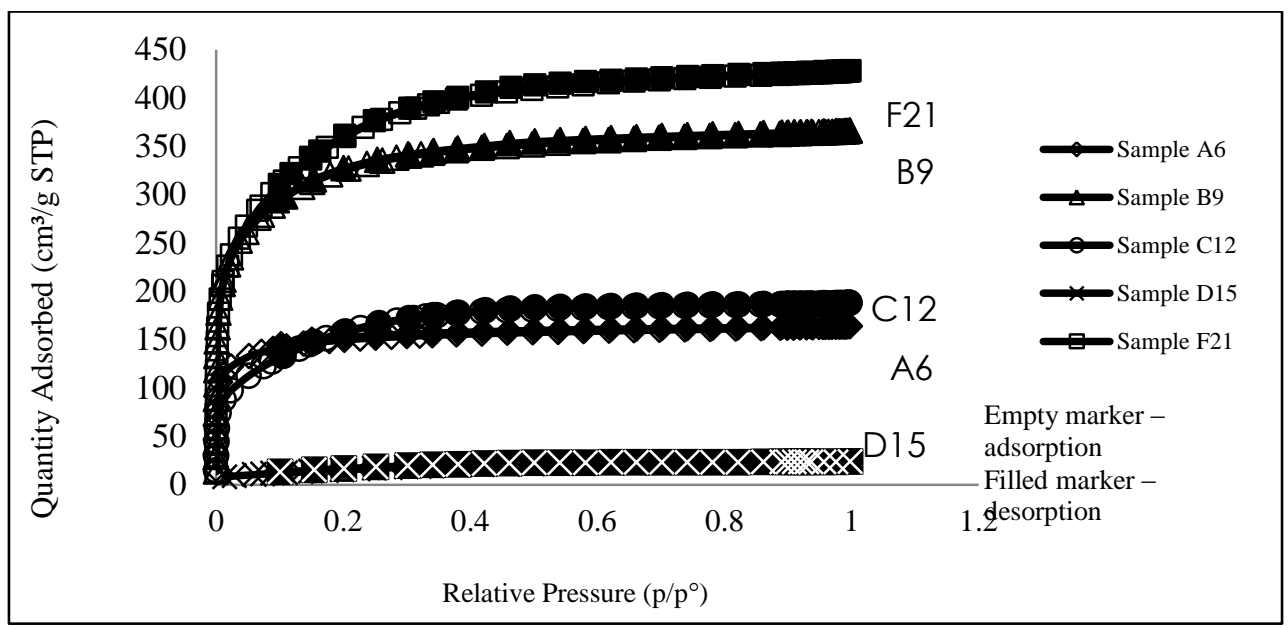

Figure 1. $\mathrm{N}_{2}$ adsorption-desorption isotherms of selected samples

\section{Morphology}

Figure 2 shows the microscopic structure of the raw sawdust and some selected samples prepared at different activation parameters. By using FESEM, structural images with magnification up to 300 times are taken. The structural image of fresh sawdust in Figure 2(a) points up that the raw material before undergoing activation shows no noticeable pores. However, the image clearly shows the existence of fine pores on the surface, which is one of the important characteristics for manufacturing AC. After activation, a greater distribution of pores emerged to become active sites for adsorption to take place more readily. The difference in pore structure before activation and after activation is clearly illustrated through comparison made between Figure 2(a) with Figure 2(b) and 2(c). Sample A6 (Figure 2(b)) shows good canal structure for the AC, meaning that the carbonization and activation are taking place but still at early stages at temperature of $400{ }^{\circ} \mathrm{C}$. Many new large pores were clearly observed on the surface of the AC. Sample F21 (Figure 2(c)) shows the most well developed porous structure among the three AC. This justified that sample $\mathrm{F} 21$ has the highest $\mathrm{S}_{\mathrm{BET}}, \mathrm{V}_{\mathrm{T}}$ and D compared to other samples. On the other hand, collapse of porous wall due to excessive heat exposure is observed in Figure 2(d) with Sample D15 being activated at highest temperature.
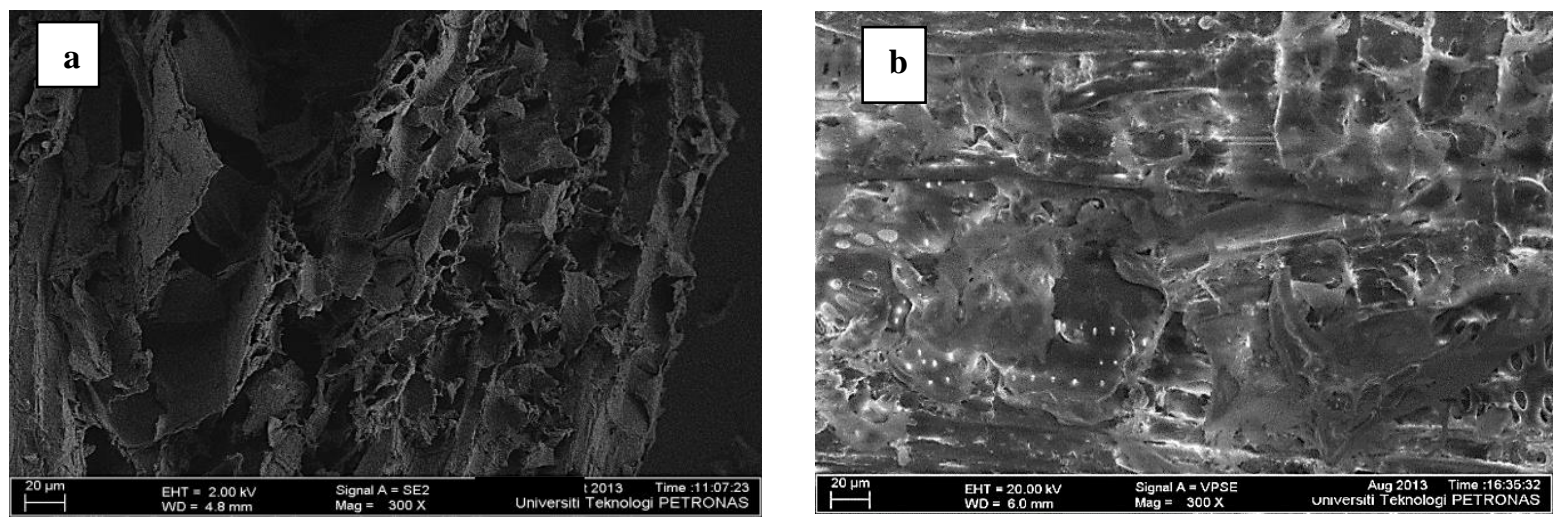

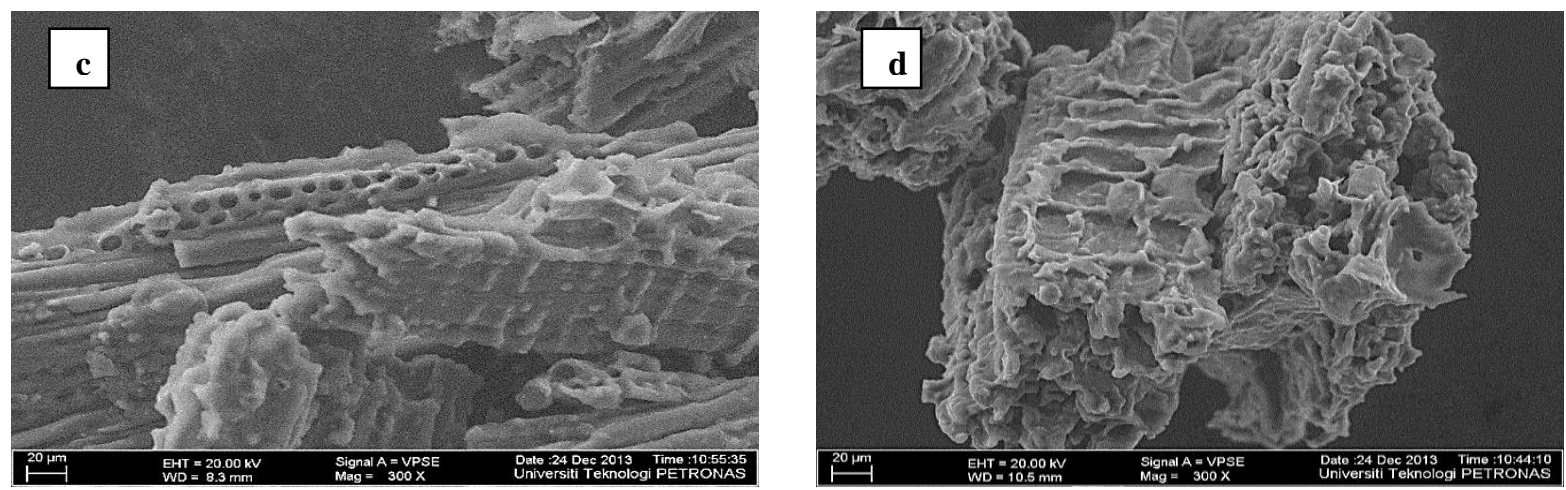

Figure 2. FESEM images of selected samples, (a) fresh sawdust, (b) sample A6, (c) sample F21 and (d) sample D15

\section{Effect of initial concentration on MEA removal}

The adsorption test on selected AC samples was conducted using synthetic MEA wastewater produced from diluting MEA with distilled water. Sample B9 and F21 having high value of $S_{B E T}$ and $V_{T}$, were selected as test subjects along with the fresh sawdust to show contrast. Figure 3 shows the plot of percentage removal against initial MEA concentration. It was revealed that at low concentration, the removal percentage was high and gradually decreased with the increase of MEA concentration. From Figure 3, MEA concentration prepared at 100 ppm, the removal percentage were 96.8, 92.7 and 4.6\% for sample F21, B9 and raw sawdust, respectively. The low percentage MEA removal for raw sawdust without activation proved that the material is not capable of adsorbing MEA due to almost no noticeable pores. Sample B9 was able to remove up to $92.7 \%$ of MEA, nonetheless, the result was surpassed when Sample F21 which has relatively higher $S_{B E T}$ and $V_{T}$, exhibited higher adsorption capacity and higher rate of adsorption. On the other hand, the highest MEA concentration at 500 ppm led to the lowest removal percentage under test $(86,85.4$ and $0 \%$ for samples F21, B9 and raw sawdust, respectively. The obtained results in the present work concerning MEA removal agreed with that obtained by Razali et al. [10] where the removal percentage of MEA was the highest at low concentration and decreased with the increase in its concentration. The reason behind this is due to the MEA molecules are no longer attached to the surface of the adsorbent since the adsorbent have reached their limited surface to adsorb. Further increase in concentrations brought no increase in adsorption, which was a result of overlapping of adsorption sites due to overcrowding of adsorbent particles.

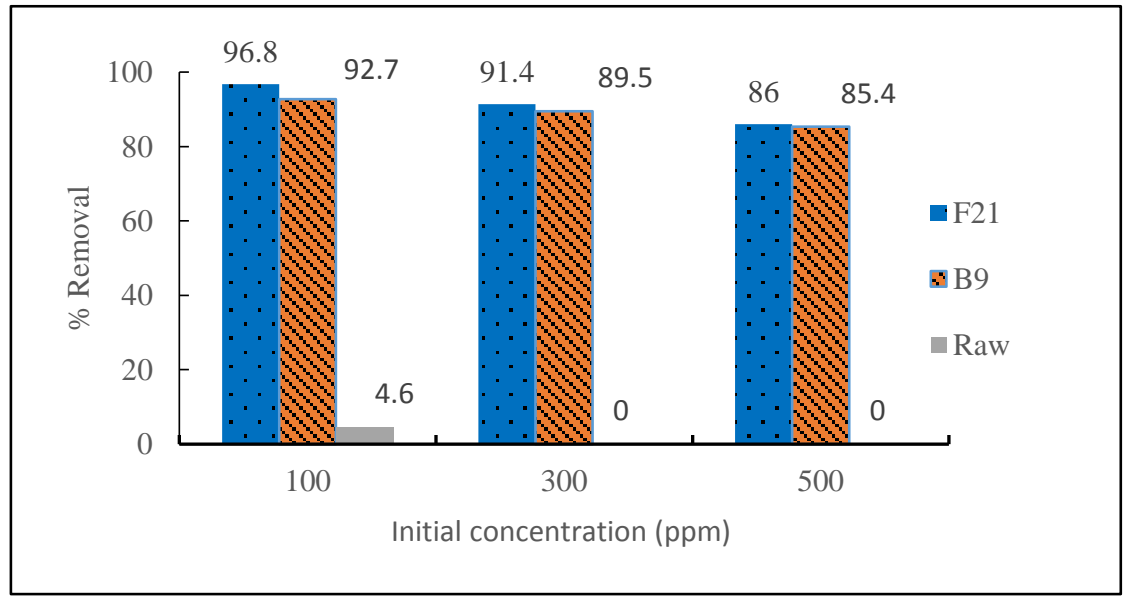

Figure 3. Effect of initial concentration on MEA removal 


\section{Azry et al: MONOETHANOLAMINE WASTEWATER TREATMENT VIA ADSORPTION USING WOOD SAWDUST BASED ACTIVATED CARBON}

\section{Effect of stirring rate on MEA removal}

The effect of stirring rate on adsorption of MEA is shown in Figure 4. In general, it was observed that when the stirring rate is increased from 200 to $400 \mathrm{rpm}$, the percentage removal of MEA also increased for all samples. Sample F21 shows the highest percentage of removal followed with sample B9 and raw sawdust. At a stirring rate of $400 \mathrm{rpm}$, maximum recoveries obtained for MEA are, 99.7\% removal for sample F21, 99.1\% removal for sample B9 and $4.2 \%$ removal for raw sawdust. Due to the existence of pore volume on the surface of B9, therefore the percentage removal is high and comparable with sample F21. With the increasing of the stirring rate, the rate of diffusion of MEA from the bulk liquid to the liquid boundary layer surrounding the AC particle become higher because of an enhancement of the turbulence and a reduction in the thickness of the liquid boundary layer [20]. This effect may be additionally enhanced by the greater fragmentation of the adsorbent particles which accompanies the increased agitation speed. As for raw sawdust, effect of stirring rate did not improve on the amount of MEA adsorbed from the bulk solution.

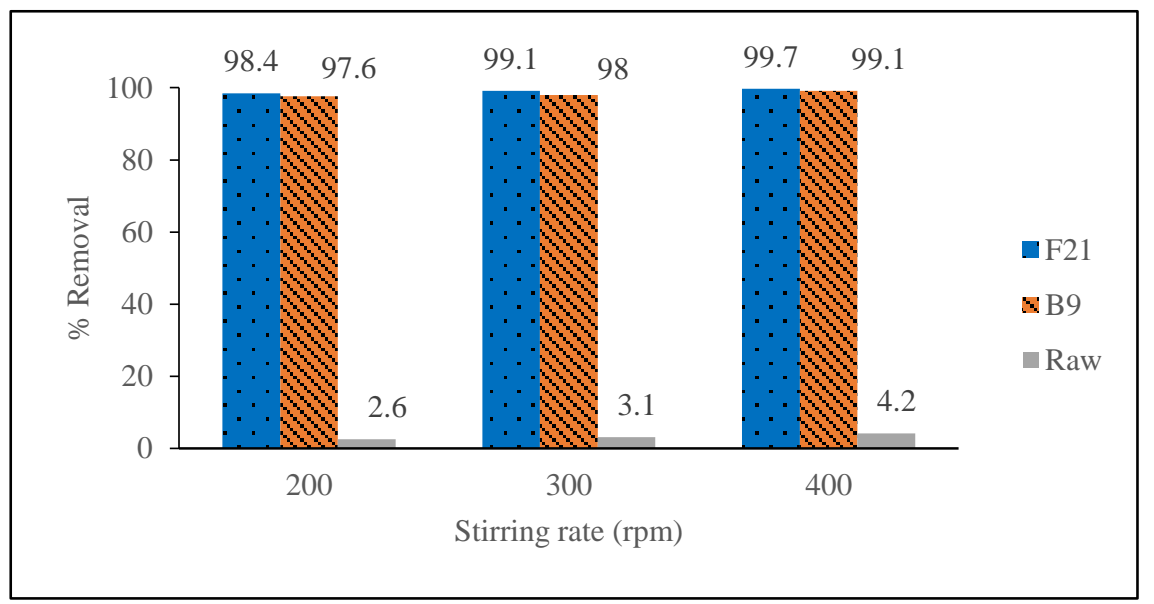

Figure 4. Effect of stirring rate on MEA removal

\section{Effect of contact time on MEA removal}

The relationship between contact time and the percentage removal of MEA with AC prepared from sawdust are shown in Figure 5. From the result obtained, it is evident that the removal of MEA increased as contact time increases. When MEA concentration prepared at $200 \mathrm{ppm}$ and contact time of 45 minutes, the removal percentage were 99.7, 98.5 and 3.8\% for samples F21, B9 and raw sawdust, respectively. This is the highest percentage removal compared than any other conditions specified. However, raw sawdust sample shows a constant MEA removal of $3.8 \%$ at contact time of 30 and 45 minutes of experiment. This is probably due to the adsorbent already achieved the optimum time to adsorb the MEA and equilibrium condition has been established [21, 22]. Increasing the contact time to promote removal of MEA will not bring any changes in the removal percentage, but probably resulted in desorption of the metal ions from the surface of the AC. 


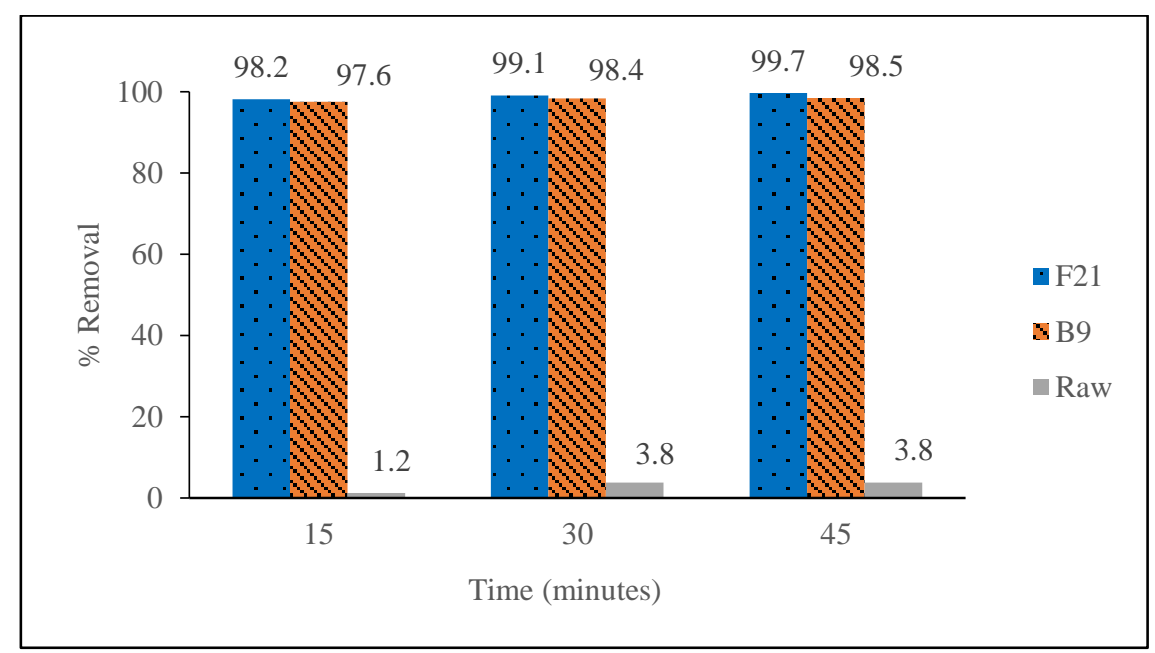

Figure 5. Effect of contact time on MEA removal

\section{Conclusion}

The result of this study clearly demonstrated that AC having high surface area and great distribution of microscopic pores can be prepared from sawdust by chemical activation with $\mathrm{H}_{3} \mathrm{PO}_{4}$. The optimal preparation process of $\mathrm{AC}$ from sawdust was successfully achieved by using one-factor-at-a-time (OFAT) method. With an IR of 1:1, $\mathrm{T}_{\text {act }}$ of $500^{\circ} \mathrm{C}$ and $t_{\text {act }}$ of 60 minutes, AC with highest $S_{\text {BET }}\left(1213.786 \mathrm{~m}^{2} / \mathrm{g}\right), V_{\mathrm{T}}\left(0.662 \mathrm{~cm}^{3} / \mathrm{g}\right)$ and $\mathrm{D}(2.18 \mathrm{~nm})$ can be produced. In addition, characterization analysis revealed that the range of pore diameter (2-6 nm) falls within mesopores group, indicating its suitability to be used for MEA adsorption. Results from batch experiments showed that sample F21 is capable of removing $96.8 \%$ of MEA at concentration of 200 ppm and $99.7 \%$ under effect of stirring rate at $400 \mathrm{rpm}$. While under the effect of contact time, 99.7\% of MEA removal is achieved at time of 45 minutes. This study confirmed that sawdust is an effective remover of MEA from industrial wastewater and has the potential to be a promising precursor for the production of AC.

\section{Acknowledgement}

The authors gratefully thank Universiti Teknologi PETRONAS for providing financial support and laboratory facilities in carrying out this research work.

\section{References}

1. Luis, P. (2016). Use of monoethanolamine (MEA) for $\mathrm{CO}_{2}$ capture in a global scenario: Consequences and alternatives. Desalination, 380: 93-99.

2. Zhang, Y., Chen, C. C., Plaza, J. M. and Rochelle, G. T. (2009). Rate-based process modelling study of $\mathrm{CO}_{2}$ capture with aqueous monoethanolamine solution. Industrial and Engineering Chemistry Research, 48(20): 9233-9246.

3. Razali, M. N. (2011). Adsorption treatment of monoethanolamine wastewater from oil and gas industry. Master Thesis. Universiti Malaysia Pahang, Malaysia.

4. Hospido, A., Moriera, M. T., Fernandez, C. M. and Feijoo, G. (2004). Environment performance of a municipal wastewater treatment plant: LCA case-studies. International Journal of Life Cycle Assessment, 10: 336-345.

5. Borhan, A., Hoong, P. K. and Taha, M. F. (2014). Biosorption of heavy metal ions, oil and grease from industrial waste by banana peel. Journal of Applied Mechanics and Materials, 625: 749-752.

6. Jahagindar, A. A., Ahmed, M. N. Z. and Devi, B. V. (2012). Adsorption of chromium on activated carbon prepared from coconut shell. International Journal of Engineering Research and Application, 2: 364-370.

7. Malaysian Investment Development Authority (2016). Industries in Malaysia - Wood based industry. http://www.mida.gov.my/env3/index.php?page=wood-based-industry. [Access online 29 December 2016].

8. Prakash, K. B. G., Shivakamy, K., Miranda, L. R. and Velan, M. (2006). Preparation of steam activated carbon from rubberwood sawdust and its adsorption kinetics. Journal of Hazardous Materials, 136(3): 922-929. 
9. Nur Izzati, A. G., Nur Yusra, M. Y., Wan Nor Roslam, W. I. and Mohd. S. M. (2017). Modification of active carbon from biomass Nypa and amine functional croups as carbon dioxide adsorbent. Journal of Physical Science, 28(1): 227-240.

10. Razali, M. N., Yunus, R. M., Jemaat Z. and Alias S. (2010). Monoethanolamine wastewater treatment via adsorption: A study on comparison of chitosan, activated carbon, alum and zeolite. Journal of Applied Sciences, 10(21): 2544-2550.

11. Mohammad, A. F. M., Yoshimitsu, U., Suzana, Y., Fathelrahman, E., Azhar, U. and Mitsuka, D. (2016). Activated carbon from rubber wood sawdust by $\mathrm{CO}_{2}$ activation. Procedia Engineering, 148: 530-537.

12. Borhan, A., Taha, M. F. and Hamzah, A. A. (2014). Characterization of activated carbon from wood sawdust prepared via chemical activation using potassium hydroxide. Advanced Materials Research, 832: 132-137.

13. Muda, A. and Hidayu, A. R. (2016). Preparation and characterization of impregnated activated carbon from palm kernel shell and coconut shell for $\mathrm{CO}_{2}$ capture. Procedia Engineering, 148: 106-113.

14. Zhang, T., Walawender, W. P., Fan, F. T., Fan, M. and Brown, R. C. (2004). Preparation of activated carbon from forest and agricultural residues through $\mathrm{CO}_{2}$ activation. Chemical Engineering Journal, 105 (1-2): 53-59.

15. Zhang, H., Yan, Y. and Yang. L. (2010). Preparation of activated carbon from sawdust by zinc chloride activation. Adsorption, 16(3): 161-166.

16. Teng, H., Yeh, T. S. and Hsu, L.Y. (1998). Preparation of activated carbon from bituminous coal with phosphoric acid activation. Carbon, 36(9): 1387-1395.

17. Borhan, A. and Kamil, A. F. (2014). Preparation and characterization of activated carbon from rubber-seed shell by chemical activation. Journal of Applied Sciences, 11: 1124-1129.

18. Girgis, B. S. and El-Hendawy, A. A. (2002). Porosity development in activated carbons obtained from date pits under chemical activation with phosphoric acid. Microporous and Mesoporous Materials, 52 (2): 105-117.

19. Mays, T. J. (2007). A new classification pore sizes. Studies in Surface Science Catalysis, 160: 57-62.

20. Koumanova, B., Peeva, P. and Allen, J. S. (2003). Variation of intraparticle diffusion parameter during adsorption of p-chlorophenol onto activated carbon made from apricot stones. Journal of Chemical Technology and Biotechnology, 78: 582-587.

21. Bulut, Y. and Tex, Z. (2007). Removal of heavy metals from aqueous solution by sawdust adsorption. Journal of Environmental Sciences, 19: 160-166.

22. Gad, H. M. H. and El-Sayed, A. A. (2009). Activated carbon from agricultural by-products for the removal of Rhodamine-B from aqueous solution. Journal of Hazardous Materials, 168: 1070-1081. 